\title{
ADDRESSING POLICE CORRUPTION IN SOUTHEAST ASIA: POLITICS, PARTICIPATION, AND PUBLIC MANAGEMENT REFORM
}

\author{
Lor Mouy Ngich \\ Master of Public Management, a Government Officer \\ at the Department of Personnel and Training, \\ General Department of Administration and Security, \\ Anti-Corruption Unit, Cambodia. \\ Address: 20B, Street 154, Sangkat Chey Chumneas, \\ Khan Daun Penh, Phnom Penh, Cambodia 12206. \\ Email: lormeiyu@gmail.com
}

\section{Wonhyuk Cho}

$\mathrm{PhD}$, Senior Lecturer of Public Management at Victoria University of Wellington, New Zealand.

Address: Room 809, Rutherford House, 23 Lambton Quay, Pipitea, Wellington, New Zealand 6011.

Email: wonhyuk.cho@vuw.ac.nz

\begin{abstract}
As people's interests and concerns on public safety have risen in Southeast Asia, academia has witnessed the growth of public management research on police corruption in the region. Little effort has been made to systematically analyse police corruption studies in Southeast Asia, therefore, we investigate what has been researched on police corruption in Southeast Asia in the field of public management. We present what research focuses there have been regarding anti-corruption measures and how they have changed over the last two decades, and then we offer suggestions for future research on this topic. Our analysis shows that political will was the most studied strategy in managing police corruption in the region, while anti-corruption agencies, police institutional reform and public participation have also been emphasized over time. Each Southeast Asian country places different emphases on these themes depending on the country's unique context and experiences.
\end{abstract}

Keywords: police corruption; Southeast Asia; public management; political will; anti-corruption agencies; institutional reform; public participation; transparency.

Citation: Ngich, L. M. \& Cho, W. (2020). Addressing Police Corruption in Southeast Asia: Politics, Participation, and Public Management Reform. Public Administration Issues, no 5, (Special Issue I, electronic edition), pp. 9-34 (in English); DOI: 10.17323/1999-5431-2020-0-5-9-34 


\section{Introduction}

Corruption has been identified as one of the most challenging hindrances for the well-performing public sector in developing countries in Southeast Asia (Jain, 2001), which is in turn hampering the socio-economic development that many governments in those regions are desperate to achieve. Among government institutions or organizations, the police department is typically known as one of the most problematic institutions that public management reforms should take strong actions on (Transparency International, 2014, 2019). Corrupt police might even strengthen the perspective of the public that there is impunity for crimes (Cho, 2017; Newham, 2000), which ultimately undermines the public's confidence in the trustworthiness and reliability of the whole justice system (Bruce, 2008).

Because corruption is a concern in most countries in Southeast Asia, many researchers of the region have been looking for a suitable anti-corruption strategies model (Graycar \& Sidebottom, 2012; Huberts \& Six, 2012; Johnston, 2005, 2013; Lasthuizen, Huberts, \& Heres, 2011; Quah, 2013; Zhang \& Lavena, 2015). International organizations and international scholars have shown interest in corruption phenomenon at a national level. For example, Johnston (2013) presented forms of corruption many countries are facing and classified four syndromes of corruption. The World Bank (2000) presented an anti-corruption model that focuses on multiple strategies which are enhancing political accountability, empowering participation from civil society, encouraging competitiveness in the private sector, and improving management practices in the public sector.

Southeast Asia has been of growing importance in international communities for its size and economic potentials (Sagarik et al., 2018), while corruption and public safety have been one of the major barriers for transnational businesses and foreign investment in the region. There is a need for understanding what we have already studied about police corruption in Southeast Asia. This research aims to collect and analyse academic research on police corruption in Southeast Asia in order to inform future researchers and policy-makers with a systematic review of knowledge in the issue. This study will also analyse how studies have approached the counter-corruption measures in police in Southeast Asian countries, based on an analytical framework drawn from the work of Quah (2013), $\mathrm{Vu}$ (2017), Newburn (1999), and Transparency International (2012, 2018a).

\section{Context: Police Corruption Status in Southeast Asia}

Police corruption is a worrying issue among countries situated in Southeast Asia. A TI survey from 2017 showed that 51 percent of respondents perceived the police as corrupt (Transparency International, 2018b). Although this represented a small decrease in the number of people who believed the police institution was corrupt, it was still a pretty serious issue. Table 1 shows that police institutions are perceived to be highly corrupt in some Southeast Asian countries, although data is not available for countries like Singapore, Timor-Leste, Philippines, Brunei and Laos. 
Table 1

Percentages of perceived police corruption in Southeast Asia

\begin{tabular}{|l|c|}
\hline \multicolumn{1}{|c|}{ Countries } & Percentages of perceived police corruption, $\%$ \\
\hline Singapore & N/A \\
\hline Malaysia & $20-30$ \\
\hline Indonesia & $30-40$ \\
\hline Thailand & $40-50$ \\
\hline Timor-Leste & N/A \\
\hline The Philippines & N/A \\
\hline Vietnam & $50-75$ \\
\hline Brunei & N/A \\
\hline Myanmar & $40-50$ \\
\hline Laos & N/A \\
\hline Cambodia & $40-50$ \\
\hline
\end{tabular}

Source: Transparency International.

Many measures have been proposed to reduce police corruption in Southeast Asia. These are usually centred on institutional reform, such as by introducing changes in the environment or organizational culture and the way the police forces are recruited and trained (Bayley \& Perito, 2011). There are other suggested strategies for combating police corruption. These include using integrity tests in the police force (Prenzler \& Ronken, 2001) to check for their complaint profiles (Prenzler \& Ronken, 2003). The World Bank (1997) suggests that the public should be involved in fighting corruption at all levels.

There is a mixture of measures used in different countries in Southeast Asia. For instance, in 1952, Singapore was the first country to establish a single and independent anti-corruption agency, called the Corrupt Practices Investigation Bureau (CPIB). Indonesia encourages people and civil societies to be involved in reporting police corruption cases (Allen et al., 2020). The government of the Philippines uses quite extreme approaches in punishment for police who are corrupt.

\section{What is police corruption and how can we deal with that:}

Concepts and framework

Corruption is commonly defined as "the abuse of public or corporate office for private gain" (World Bank, 1997, p. 8). Transparency International (2015a) extends this definition, and states that corruption could be categorized into three types: grand, petty, and political corruption. This depends on the amounts of money involved and the scope of corruption. Johnston (2013) emphasized two keywords when he defined corruption: "public roles" and "resources". Despite at- 
tempts to give definitions to the term corruption, there is no single agreed definition. Therefore, international organizations, such as the United Nations Convention against Corruption (UNCAC) and the OECD, instead of defining the term, describe particular crimes regarded as corrupt practice (U4 Anti-Corruption Resource Centre, 2010).

The term "police corruption" is defined similarly to the term "corruption" in general as it is a form of corruption committed by public bureaucracy. Nye (1967, p. 416) defines police corruption as "behaviour that deviates from the formal duties of a public role (elective or appointive) because of private-regarding (personal, close family, private clique) wealth or status gains". Therefore, police corruption is an act by a police officer (regardless of their rank) in providing information, using his or her rights or power to offer any support to a third party without permission, or illegally disobeying organizational rules in exchange for money or valuable goods or services from a third party.

The literature on corruption prevention is reviewed to guide this research with an analytical framework. Researchers have conducted studies on police corruption in different countries with different focuses, and this article employs an analytical lens from previous works relevant to the region: Southeast Asia. Quah is an AntiCorruption consultant based in Singapore and his work focuses on how Singapore has turned from a highly corrupt country to one of the least corrupt countries in the world. Quah (2006, 2014) studied Singapore's anti-corruption strategy and describes how the country was successfully curbing corruption. Many researchers in this field have followed his framework.

Quah's work is mostly intended to show the reasons why Singapore has been a successful country in controlling corruption, while Newburn's five strategies targeted at police corruption could be more applicable in many other contexts. Transparency International $(2012,2018 b)$ analyses the occurrence of corruption in different countries. The research of Transparency International is somewhat similar to the framework from previous researchers which could help frame a means of police reform. Vu (2017) shows that Quah's institutional framework in fighting corruption should be revised in Vietnam because other factors play critical roles in making corruption persistent in this country. These factors include history and culture, economic management, and the administrative system of the country. Buttle, Davies, and Meliala (2016) suggest a cultural constraint theory of police corruption in Indonesia, which explained why corruption occurs in this country. Gutierrez-Garcia and Rodriguez (2016) proposed that achieving reductions in police corruption also needs other social indicators, such as welfare and benefits, to be improved. Zhang and Lavena (2015) analysed case studies of anti-corruption strategies in different countries, namely Singapore, South Korea, Qatar, and the UAE. They found that some anti-corruption strategies are effective because anticorruption laws are strictly enforced and implemented, anti-corruption institutions are empowered, and public engagement is involved.

In this article, we use an analytical framework inspired by Quah's work to analyse the research focus of police anti-corruption measures, but we modified his model with the other research which complement each other. We analyse public participation, police institutional reform, anti-corruption agency, and political 
will as counter-measures for police corruption in Southeast Asia. The framework of this research integrates the critical points from multiple sources. The checklist for curbing police corruption is created with the four themes because the researcher believes that both internal and external institutions are required.

\section{Political will}

Transparency International (2015b) defines political will as politicians' commitment to addressing problems society is faced with, namely supporting reform nationwide and responding with well-planned policy. Political will from the government and external pressure have been discussed to contribute to the effectiveness of anti-corruption strategy design and implementation. Quah (2013) argues that the success of effective anti-corruption strategies in Singapore are from a government that has a strong political will to curb corruption, which in turn placed enough resources for the anti-corruption institution to use. Scholars have described political will as one of the most important elements in promoting good governance and reducing corruption. If there is weak or a lack of political will, then anti-corruption reform cannot harvest the results it is aiming for (Persson et al, 2013). Kpundeh and Hors (1998) state that political will is of crucial importance in strengthening transparency and accountability in practice because without authentic willingness to reduce corruption, there will be only words and statements.

Senior (2006) points out that politicians will use their authority to reform, adopt laws, and offer sufficient resources and funds for the implementation of designed strategies when they have the political will. In the same vein, Quah (2013) asserts that there is political will when a country has introduced comprehensive anti-corruption regulations, and the anti-corruption agency is independent and equipped with adequate staff and funds.

As far as the external environment and external controls are concerned, it is believed that police are corrupt because of pressures from outsiders or the environment around them. Therefore, rather than targeting change in police organizations, a policy aiming to restructure the social environment is of great importance (Newburn, 1999). Sherman (1978b) states that external pressure, mainly resulting from a rampant corrupt political setting, contributes to corrupt practice in police units.

\section{Public participation}

Public participation is defined as involvement of individuals/groups that are affected by a proposed intervention subject to a decision-making process (World Bank, 2006; Cho \& Ho, 2018). According to Verdenicci and Hough (2015), when citizens were encouraged to act as whistle-blower reporting any experiences of corruption through a participatory initiative, corruption may well be discovered. For example, Bhargava (2015) presented the results of public participation in different countries and showed that a variety of citizens' activities can have different effects at different levels and dimensions. These include better management of finance, natural assets, and delivery of a public service with accountability by monitoring, using citizen report cards and interest litigation. Ackerman (2004) suggested that if provided opportunities, citizens can request accountability from state institutions 
and reduce room for corruption through different approaches by being involved in promoting transparency. More access to public information encourages people to punish elected officers and select those more accountable for the next elections.

\section{Anti-corruption agencies}

The OECD (2013) states that anti-corruption agencies (ACAs) are established to solve and reduce corruption issues through their main functions. The five functions of ACAs are to investigate and prosecute, prevent, educate and raise awareness, coordinate, and monitor and research corruption. Roles of ACAs are different in different contexts. Some ACAs are responsible for enforcing the law, while others take on preventive roles or other roles simultaneously. Some countries do not have any specific ACAs, but the government agencies have divisions to combat corruption (the OECD, 2013). UNDP (2011) focus on the capability of ACAs in performing their roles, including skills, expertise in investigation and prosecution, and ability to use technical resources to solve corruption cases. On the other hand, Quah (2011) argues that without law enforcement, ACAs' roles in detecting and punishing those found guilty is low. This is also a main justification for ineffective anti-corruption reform when law is not enforced strictly in some Asian countries, while countries with strong law enforcement succeed in controlling corruption to a satisfactory degree.

\section{Police institutional reform}

The last element is the effect of a country's policy context on anti-corruption reform. Enhancing the effectiveness of anti-corruption efforts requires a favourable policy context (Quah, 2013; Brinkerhoff, 2000). This is because the external environment could contribute to the results of anti-corruption measures and initiatives. Policy context includes geography, history, economy, demography, and politics of a country. All of these environmental factors can potentially affect the decision-making of political leaders either positively or negatively (Quah, 2011).

The first strategy focuses on the methods used to recruit police, which include pre-employment screening (Arrigo \& Claussen, 2003; Dantzker, 2011). The selection has the aim of detecting a person's character, which might influence their integrity. Furthermore, the way police are trained to differentiate right and wrong conduct is also counted as a measure to prevent police from committing corruption (Lamboo, Lasthuizen, \& Huberts, 2008). In addition to this, developing pride in the police unit is regarded as a method of human resource management to prevent corruption. This is based on the assumption that if police officials are in charge of law enforcement, they will be more careful and prevent themselves from committing crimes and corruption since they are proud of their roles (Newburn, 1999). A higher level of measure to regulate police corruption is holding police supervisors accountable for the conduct of subordinate police officers under their control (Klaver, 2013).

The policies proposed by Newburn in anti-police corruption are involved with endorsing the adoption of ethical codes in the police work culture. This policy is also supported by police units. For instance, the International Association of Chiefs of Police (2014) introduced a set of standardized codes of conduct for the police. Another strategy to combat police corruption is through the creation 
of more responsibility for police supervisors and the nature of ethics commissions. This entails putting them in charge of endorsing the ethical code in their departments and offering a confidential consultation to police when they are faced with ethical problems (Newburn, 1999; Punch, 1994). Additionally, as shown by Small and Dickie (2003), providing rewards when police demonstrate high ethical behaviours can prevent them from becoming corrupt.

Regarding the internal control measure, this aims to improve the procedures of police units internally. Namely, Newburn (1999) suggested a set of eliminating corruption-prone processes. Furthermore, this strategy might lead to the establishment of supervision programs for police officials. This can be seen in the case of Australia where the Victoria Police used reports recorded by citizens to create an early warning scheme of police officials (Macintyre, Prenzler \& Chapman, 2008). By doing this, complaints filed by citizens about a particular police official accumulate to warn of potential and severe misconduct committed by that police officer. A further successful technique under the internal control policy in reforming police institutions can be seen in the case of Georgia. Di Puppo (2010) found that in Georgia, police corruption is reduced due to an increase in salaries, the restructuring of the public image of the police unit, and the endorsement of a new governing agenda. Another typical type of internal control for anti-corruption in the police institution is using secret officials to supervise and inspect possible corruption practice (Girodo, 1998). In addition, tests for police integrity and polygraph tests are widely used for internal control purposes (Prenzler, 2009).

Table 2

Summary of the relevant theoretical frameworks

\begin{tabular}{|c|c|c|c|c|}
\hline $\begin{array}{c}\text { Quah's framework } \\
\text { on effective } \\
\text { anticorruption } \\
\text { strategy }\end{array}$ & $\begin{array}{l}\text { Vu's finding } \\
\text { on persistence } \\
\text { of corruption } \\
\text { in Vietnam }\end{array}$ & $\begin{array}{l}\text { Newburn's } \\
\text { five strategies } \\
\text { to curb police } \\
\text { corruption }\end{array}$ & $\begin{array}{c}\text { Transparency } \\
\text { International } \\
2020, \\
\text { World Bank }\end{array}$ & $\begin{array}{c}\text { Transparency } \\
\text { International } \\
2018\end{array}$ \\
\hline $\begin{array}{l}\text { - Political will } \\
\text { - Expertise } \\
\text { - Enforcement } \\
\text { - Policy context }\end{array}$ & $\begin{array}{l}\text { - Quah's } \\
\text { framework } \\
\text { - History } \\
\text { - Culture } \\
\text { - Economic } \\
\text { management } \\
\text { - Public } \\
\text { administration } \\
\text { - Political system }\end{array}$ & $\begin{array}{l}\text { - Human resource } \\
\text { management } \\
\text { - Anti-corruption } \\
\text { policies } \\
\text { - Internal control, } \\
\text { and } \\
\text { - External } \\
\text { environment } \\
\text { and external } \\
\text { control } \\
\text { - Possible } \\
\text { unintended } \\
\text { consequences } \\
\text { of corruption } \\
\text { control }\end{array}$ & $\begin{array}{l}\text { - Institutional } \\
\text { reform } \\
\text { - Community } \\
\text { policing } \\
\text { - Role of civil } \\
\text { society }\end{array}$ & $\begin{array}{l}\text { Preventative approaches } \\
\text { - Human resource } \\
\text { management systems } \\
\text { - Management and } \\
\text { administrative systems } \\
\text { - Leadership } \\
\text { - Building ethical culture } \\
\text { and professionalism } \\
\text { - Engaging with } \\
\text { the community } \\
\text { Punitive approaches } \\
\text { - Stricter sanctions } \\
\text { and enforcement rules } \\
\text { - Internal accountability } \\
\text { - External oversight } \\
\text { - Effective complaints } \\
\text { mechanisms }\end{array}$ \\
\hline
\end{tabular}


Figure 1: Relationship between relevant theoretical frameworks
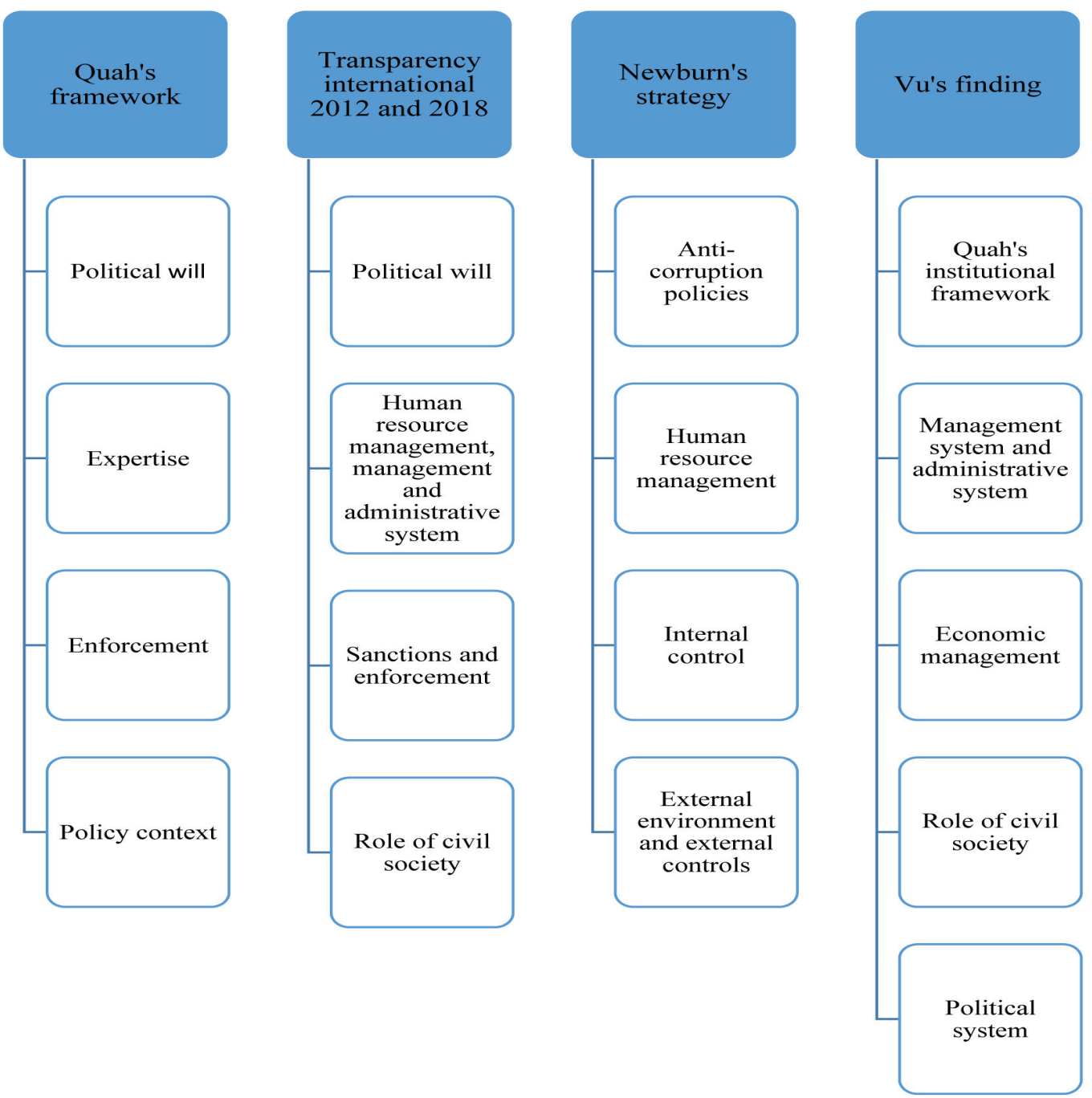

\section{Data and Method}

To conduct a systematic literature analysis, this research used secondary published data from various sources. The timespan of the selected articles ranged from 2001 to 2019. However, the references therefore are mainly from peer-reviewed journal articles, but we included handbooks, book chapters, working papers, and theses if they were academically oriented. Web of Science is used as a systematic way of collecting the data. The keywords used to locate the selected materials were "police corruption," "Southeast Asia," "transparency," and "police reform." De Montfort University (1989) suggests using keywords to allocate relevant sources when researchers use databases to find pertinent articles or information. Country names are used as keywords to locate articles too. These are "Singapore, Malaysia, Brunei, Indonesia, Thailand, the Philippines, Myanmar, Cambodia, Laos, Vietnam, and Timor-Leste." A total of 82 articles were collated for analysing. The articles then were skimmed to assess against the themes and sub-themes in the conceptual framework. 
Figure 2: Number of articles on police corruption in Southeast Asia over time

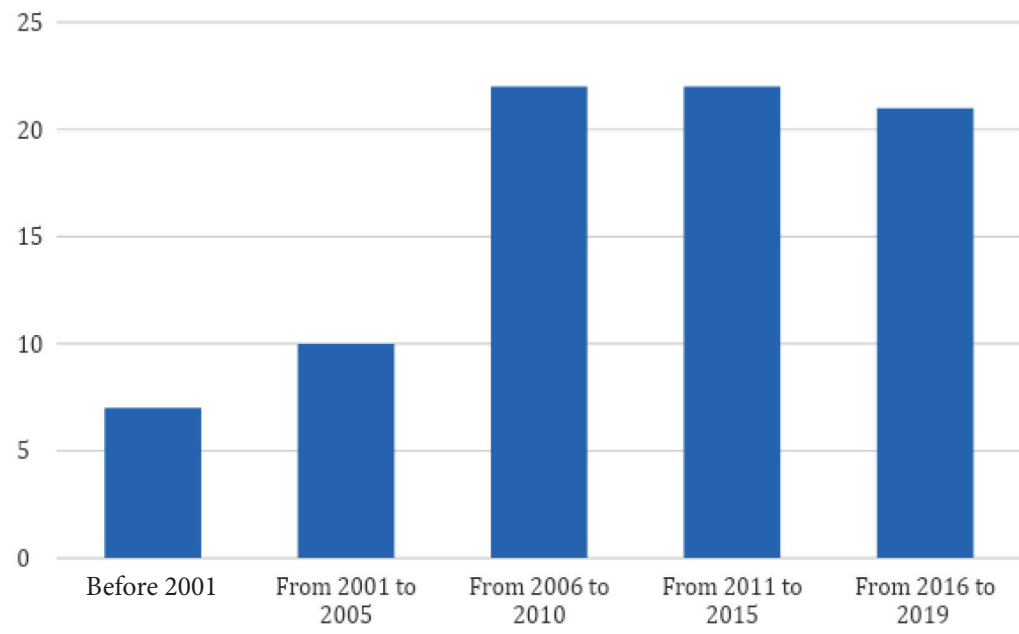

Eighty-two articles were collected and analysed to examine the trends of police corruption-related articles in Southeast Asia. There has been an increase in the number of published articles studying corruption related to police departments or other fields in Southeast Asia. Before 2000, only seven articles relating to police corruption in Southeast Asia were published. From 2000 to 2005, ten articles were published. This number has increased considerably over the last 15 years. It is evident that researchers are more concerned about police corruption in these countries, and more documents and data related to this issue are available.

Figure 3: Sources

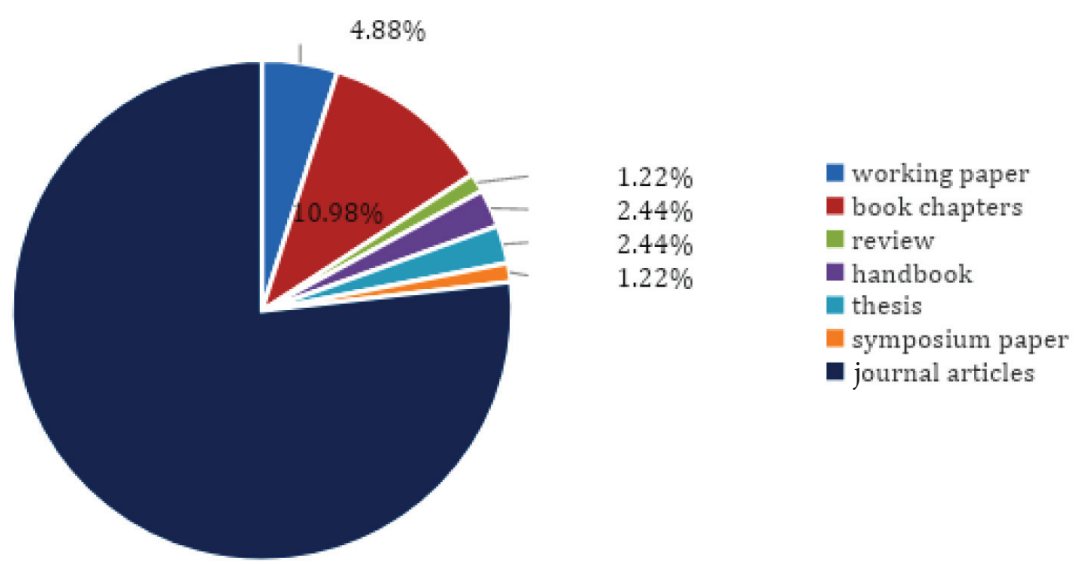

Some articles were not published in journals but in other academic sources, such as book chapters and handbooks. Because this study is concerned with academic research, journal articles are the most critical and typical source. As shown in Figure 3, the majority of sources of this study are from journals (63 of the 82 articles are published in journals), while the remaining 19 articles are from handbooks, book chapters, working papers, and theses. 


\section{Figure 4: Total number of police corruption articles by country}

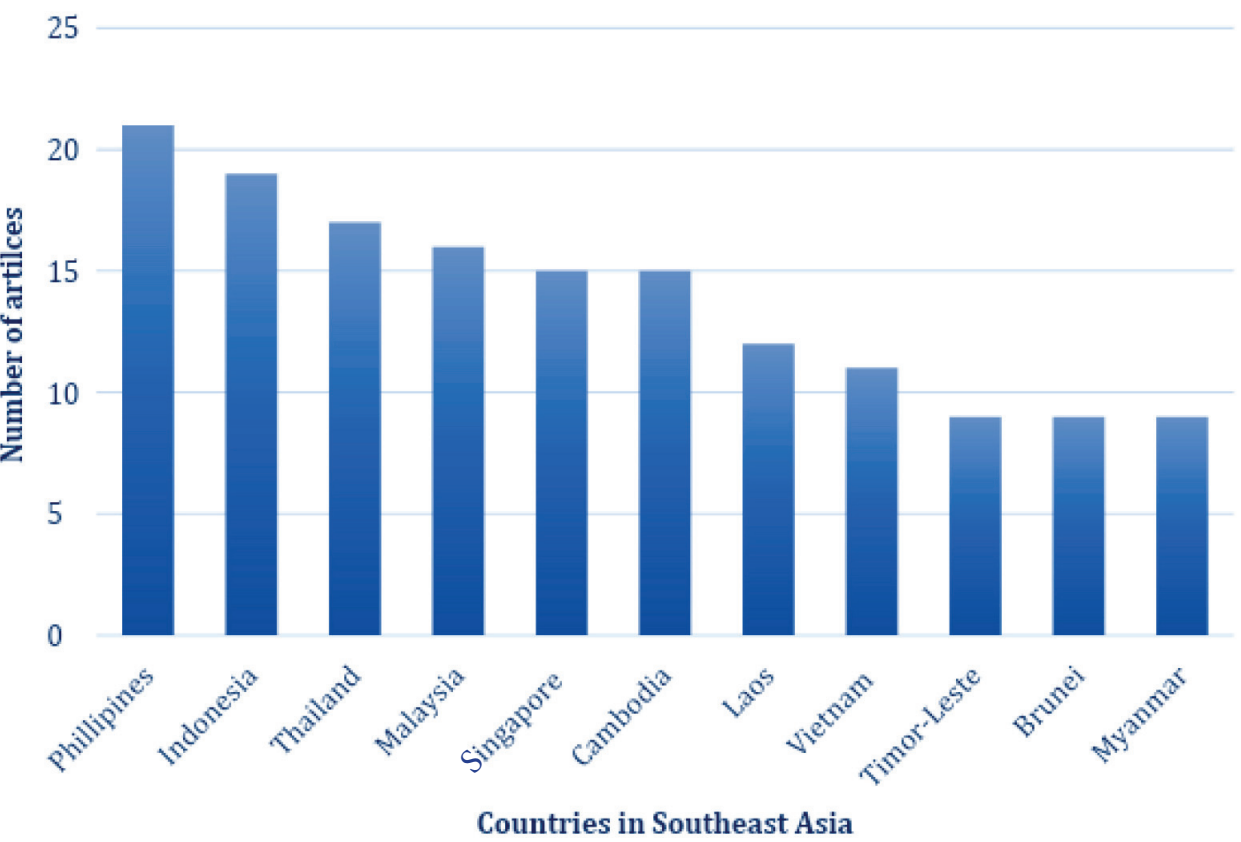

Figure 5 demonstrates the number of articles (out of 82 in total) in which the name of the country appears. Most of these articles are single country-oriented; however, there are a few articles that include all of Southeast Asia. Other articles compare two or more countries. From Figure 4, the most studied country is the Philippines (11 articles) followed by Indonesia ( 8 articles). On the other hand, Brunei, Myanmar, and Timor-Leste are the least studied by researchers. Similarly, looking at Figure 5, the Philippines (21 articles), Indonesia (19 articles) and Thailand (17 articles) are the countries that have been studied the most concerning police corruption among 11 countries in Southeast Asia.

\section{Findings}

Table 3 summarizes the main themes appearing in the articles collected. Besides the four themes in the conceptual framework, there are other themes mentioned in relation to police corruption in Southeast Asia. In the following sections, graphs are used to show findings and descriptive statistics.

From the conceptual framework, our analysis focuses on four main themes in anti-corruption measures: political will, ACAs, police institutional reform, and public participation. As shown in Figure 6, 54 articles mention political will or political commitment, while 43 articles present the concepts of ACAs and police institutional reform equally, and 32 articles raised the concept of public participation. Political will is found to be the most-studied theme among the four aspects, while public participation is the least discussed theme.

Figure 5 shows that in every period, political will has been the most studied focus of the articles, although other topics have increased in proportion. Before 
2005, police institutional reform was the second most mentioned theme, followed by ACAs. However, the trend reversed after 2010 and public participation started to appear in articles even more than ACAs and almost equally to police institutional reform. Before 2001, not one article mentioned public participation. The percentages rose considerably, to almost 27\% from 2001-2005, making it the second most mentioned theme. In subsequent time periods, the mention of public participation in journal articles has decreased considerably. Interestingly, there were big gaps among the four themes in the first three periods. However, these gaps started to narrow from 2011. This implies that the other three themes are given more attention as with political will. Political will in most of the articles is described as a prerequisite condition to fight police corruption. Quah (2013), $\mathrm{Vu}$ (2017), and Gregory (2016) argue that countries that have governments with strong political will who allocate resources and empower ACAs to educate, prevent and investigate corruption-related crimes are likely to succeed in reducing police corruption. However, many scholars and international institutions suggest that in addition to political will, multiple solutions should be employed, including reforming police institutions, educating the public, engaging the public and civil society, and empowering ACAs as an independent institution (Ackerman, 2004; World Bank, 2006; Verdenicci \& Hough, 2015; Transparency International, 2018a). This might be a reason for the gap becoming narrower and views becoming more balanced.

Table 3

\section{Themes appearing in all 82 articles}

\begin{tabular}{|c|c|}
\hline Themes & Include the Words of \\
\hline Police misconduct & $\begin{array}{l}\text { Bribery, extortion, corrupt, ask for money, coercion, violence, } \\
\text { excessive use of force, false accusation, coercion of confession, unethical, } \\
\text { misconduct, crime, deviance, brutality, occupational fraud }\end{array}$ \\
\hline Country comparison & Country names, patterns, trends, tendency \\
\hline $\begin{array}{l}\text { Factors affecting police } \\
\text { corruption }\end{array}$ & $\begin{array}{l}\text { Justice system, legal system, social, patronage, political, political economy, } \\
\text { policy context, culture, social determinants, social norms, governance, } \\
\text { rule of law, administrative, local ideology }\end{array}$ \\
\hline Public participation & $\begin{array}{l}\text { Media, newspapers, watchdogs, civil society, public, people, citizen, } \\
\text { involvement, citizen review, citizen oversight, public awareness, } \\
\text { engagement, cooperative actions }\end{array}$ \\
\hline Police reform & $\begin{array}{l}\text { Institutional reform, recruitment and selection procedures, increase } \\
\text { salary, training program }\end{array}$ \\
\hline ACAs & $\begin{array}{l}\text { Law enforcement, capability, ability, measures, initiatives, law, strategies, } \\
\text { actions, whistle blower protection, committees }\end{array}$ \\
\hline Political will & Politicians, willingness, commitment, wish, order, intend, attempt \\
\hline $\begin{array}{l}\text { Other emphasized } \\
\text { words }\end{array}$ & $\begin{array}{l}\text { Ethics, accountability, transparency, integrity, governance, the rule of law, } \\
\text { opportunity }\end{array}$ \\
\hline
\end{tabular}

Note: The bold rows are the four themes on anti-corruption measures included in the conceptual framework. 


\section{Figure 5: Number of articles by anti-corruption measures}

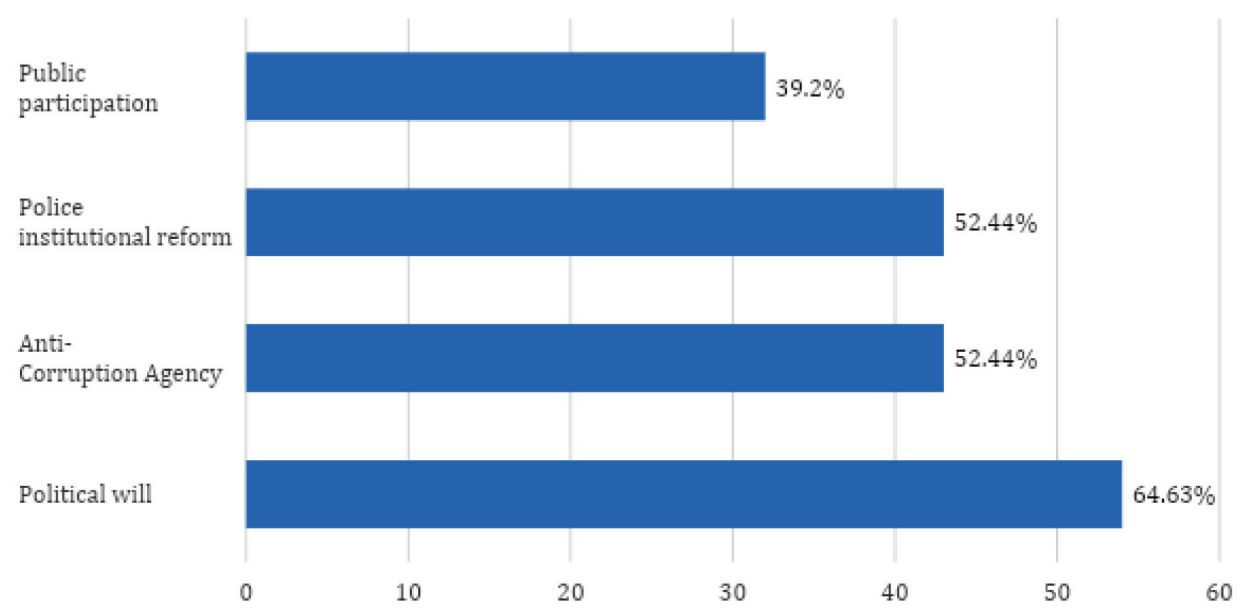

As shown in Figure 6, public participation as an element of fighting police corruption started to emerge after 2001. This is reflected in the paradigm of public management in Southeast Asian countries. Solutions to social problems in Southeast Asia have been increasingly dealt with by various forms of partnerships and cooperation among actors, including civil societies. The emerging public participation trend could be due to the growing influence of media, social media, and non-governmental organizations (NGOs)/civil society. Mendelson (2015) states that governments can no longer suppress information from the public due to advanced technology in the region, because people have access to information through different mediums.

\section{Figure 6: Percentage of each theme in different periods}

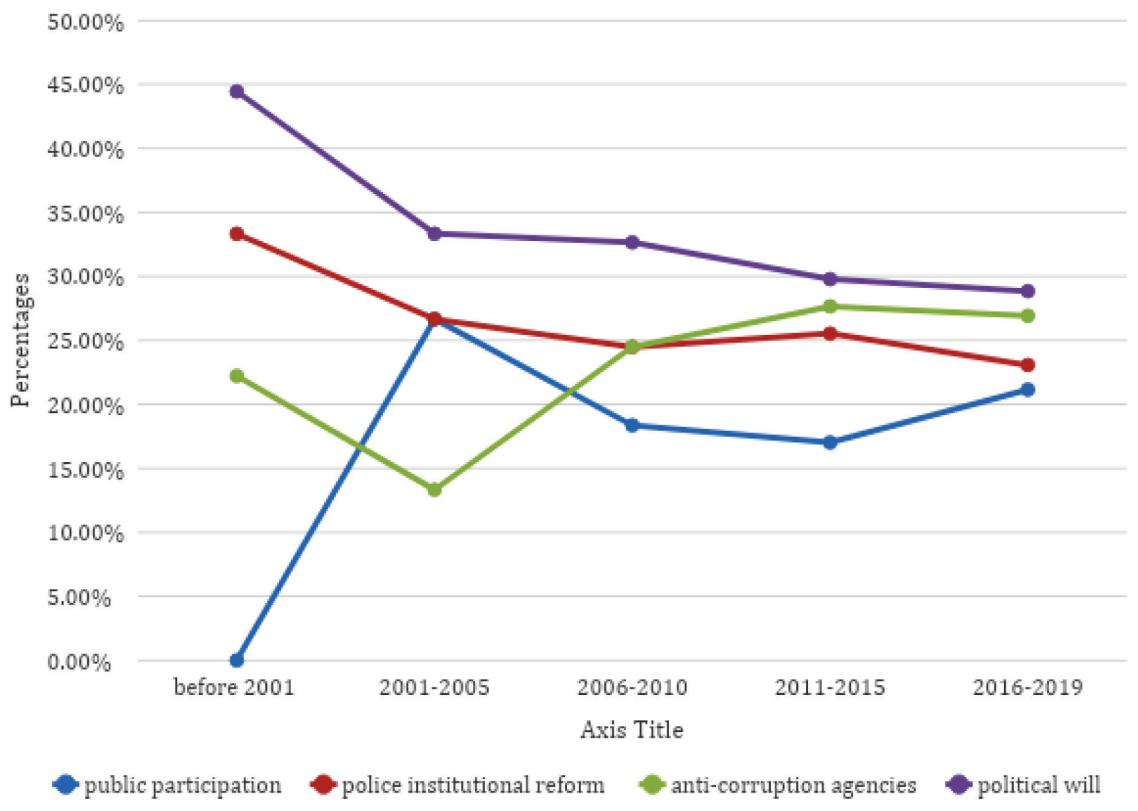


ACAs as a research theme for anti-corruption measures for police began to rise after 2005. This could be due to the late establishment of ACAs in some Southeast Asian countries, such as Timor-Leste, Myanmar, Laos, and Cambodia. For instance, ACAs were established in 2009, 2010 and 2013 in Timor-Leste, Cambodia and Myanmar, respectively. A few articles studied the functions of these agencies and the importance of having such agencies in general.

\section{Public participation}

Figure 7 shows the number of articles published in different periods about police corruption in Southeast Asia that include the concept of public participation. In general, starting in 2001, scholars began to incorporate the idea of civic engagement by citizens and/or non-governmental organizations. Articles about police corruption in Indonesia mentioned public participation in almost every period, while articles onTimor-Leste and Laos mentioned it the least. The graphs show that before 2001, there was not a single article mentioning anything about this concept in any of the countries. After 2001, there was at least one article stating this concept in each country. No published police corruption articles on TimorLeste, Vietnam and Myanmar raise public engagement from 2006-2015. While only one article about Laos and three articles about Indonesia were published from 2006 to 2015, two articles were published for each of Singapore, Thailand, and the Philippines over the same period. There were three articles about Vietnam and Myanmar and four articles about Indonesia from 2016 to 2019. These figures indicate that the concept of having public engagement in fighting corruption and police corruption started to emerge only in the 21 st century.

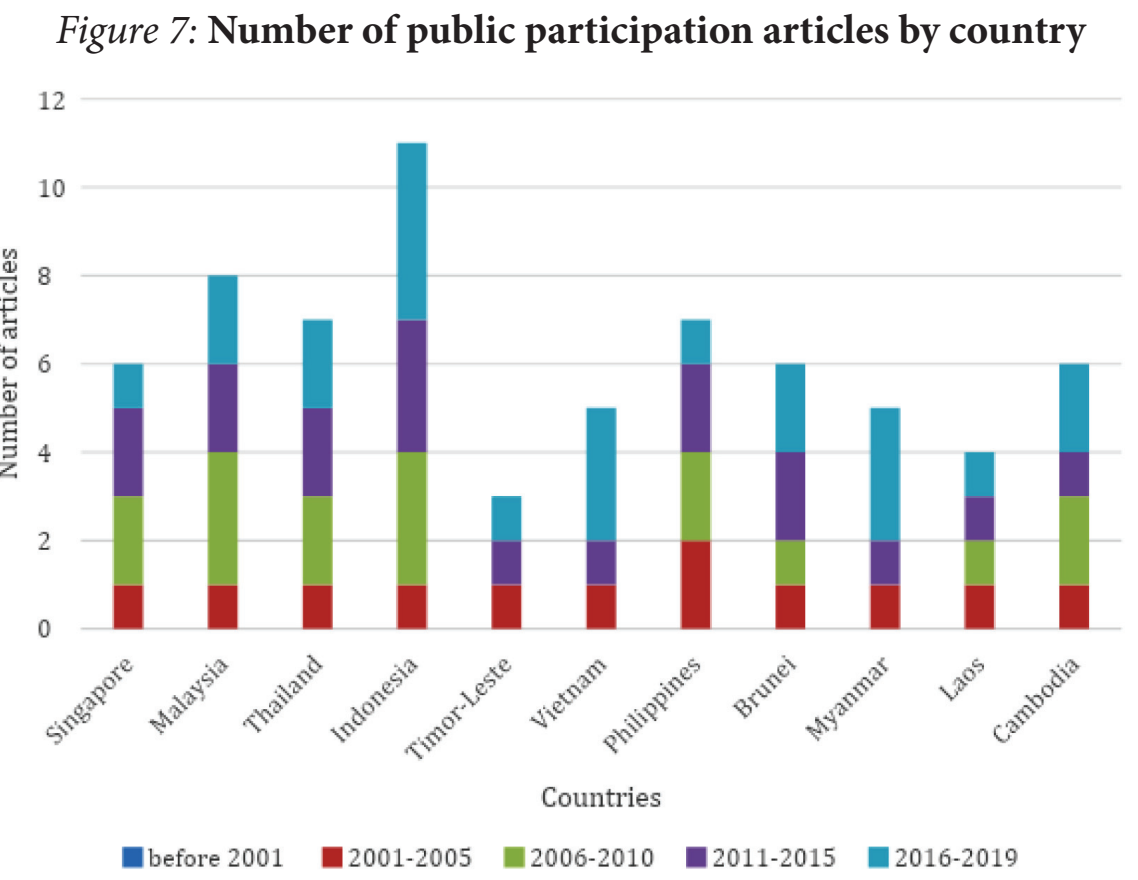

Note: some articles cover more than one country; in this case, political will is counted based on the number of nations mentioned in those articles. Therefore, the total number is over 82 articles. 
Public participation seems to appear in some of the 82 articles. Despite insufficient evidence to show the correlation between an increase in public participation and a reduction in police corruption, some researchers urge that the public should participate or engage in fighting corruption in general and police corruption in particular. This can be in the form of filing complaints and reporting corruption cases. Additionally, civil society plays a vital role in overseeing the way the police perform their tasks and whether corrupt practice occurs in police institutions. Civil society can be watchdogs and reporters to better inform the public about police corruption in a country. For instance, Feinberg (2009) states that the Cambodian government recognized the importance of reform in the judiciary and enforcement of the law. However, corruption committed by police officers and judges in Cambodia is still unresolved, although there are reforms in place. About 30 non-governmental organizations (NGOs) are working on such reforms. They are involved in training journalists, commentators and those working in the field of media to distribute information related to police and judiciary corruption and other breaches of the law to the public. These NGOs help coordinate donors' funds to ensure that funds are not captured by public officers. Correspondingly, Setiyono and Mcleod (2010) assert that civil society organizations (CSOs) have pushed for the adoption of new laws and the establishment of new institutions to work in eradicating corruption in Indonesia. There are also cases where corrupt officials have been punished for their actions after the engagement of CSOs.

\section{Police institutional reform}

From Figure 8, in general, there is an increase in the pattern of including police institutional reform in articles about police corruption in Southeast Asian countries. There are eleven articles about police corruption in the Philippines which raise police institutional reform, and ten articles on this topic in both Thailand and Indonesia. Police institutional reform has been least mentioned in articles about police corruption in Timor-Leste - five articles. Before 2001, there were a total of five articles mentioning police institutional reform in Singapore, Malaysia, Thailand, and Indonesia. From 2016 to 2019, the number of articles referring to police institutional reform in Indonesia and Vietnam is six, followed by Brunei and Myanmar with five articles. Interestingly, there were no articles published before 2010 discussing police institutional reform for both Brunei and Myanmar. As can be seen from the graph, Indonesia is the only country to have had at least one article discussing police institutional reform in every period. Laos is next with at least one article raising the concept of police reform in four of the five periods.

Some articles stressed that police institutions should be reformed to reduce police corruption itself. Newburn (1999) and Gutierrez-Garcia and Rodríguez (2016) state that how police institutions function and operate should seriously be taken into account to prevent and control police corruption. There should be thorough processes of recruitment to ensure newly recruited police embrace the highest standards of ethics and integrity. This can be done through psychological screening at the pre-employment stage to detect signs of corruption. Ad- 
ditionally, training sessions can also reduce attempts to commit bribery by informing police about ethics, right and wrong, and how they will be punished if found to be corrupt.

\section{Figure 8: Number of articles raising police institutional reform at different time periods in Southeast Asia}

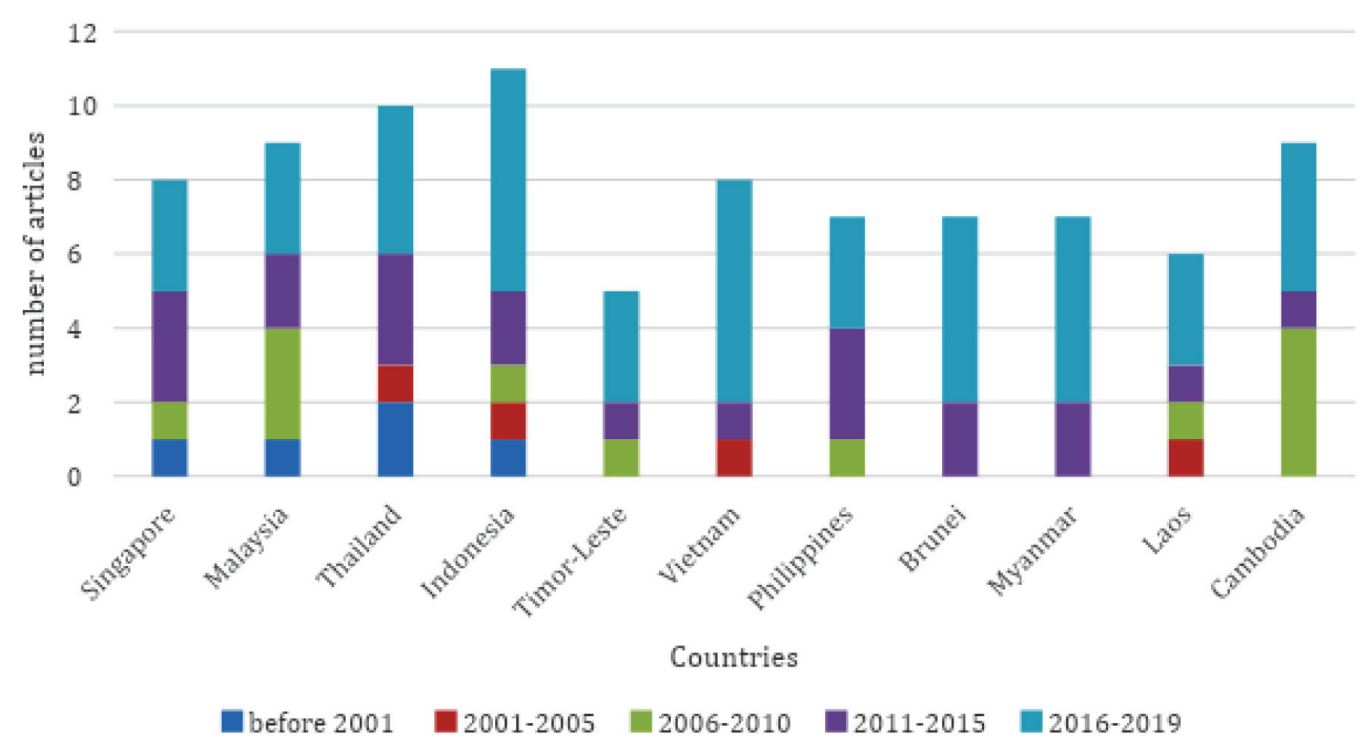

Furthermore, governments should increase police remuneration to reduce corruption in police units. Some police are corrupt because of their low salaries (Prateeppornnaronga \& Young, 2019; Case, 2008; Vichit-Vadakan, 2011; Gonzalez, 2011). This is possibly due to the fact of low payment rates for police officers and poor recruitment processes to select capable and ethical police officers. For instance, in Indonesia, the lowest ranking police officers' monthly salaries only increased to 116.9 USD in 2015 (Parlina \& Sundaryani, 2015). This is even lower than that of Cambodian police officers. Police officers with the rank of staff sergeant were paid 160 USD, and the lowest ranking police officers were paid 135.25 USD in 2015 (Hul, 2015). However, at the same time that more benefits are offered for police officers, internal accountability should also be improved by introducing programs that supervise police officers. Tests and polygraphs can be introduced in the later stages to detect corrupt behaviour and practice in police institutions. Broadhurst and Bouhours (2009) state that the Australian government's technical and financial support in the police reform in Cambodia are targeted at preventing crimes, maintaining prisons, and preventing police from being corrupt. They conclude that police corruption continues to thrive and become difficult to solve because police officers are underpaid, poorly trained, and led by patron style leaders.

\section{Anti-Corruption Agencies (ACAs)}

It can be seen from Figure 13 that overall, the trend of including ACAs has fluctuated over time. Figure 13 shows that ACAs have been mentioned the most 
in articles on police corruption in Indonesia with 13 articles, followed by Singapore with 11 articles. Four articles about police corruption mentioned anti-corruption in these three countries from 2001 to 2005 . However, the concept has been discussed least in Timor-Leste and Laos articles. Timor-Leste had the fewest with only two articles, from 2016 to 2019, and in Laos where there were two articles for each period (2006-2010 and 2016-2019). There were four articles apiece for Brunei, Myanmar, and Cambodia, about police corruption that mention ACAs, from 2016 to 2019. There was at least one article mentioning ACAs in Thailand, Indonesia and the Philippines in each period, while there were no articles at all for some periods for the remaining countries.

\section{Figure 9: Number of articles raising ACAs at different time periods in Southeast Asia}

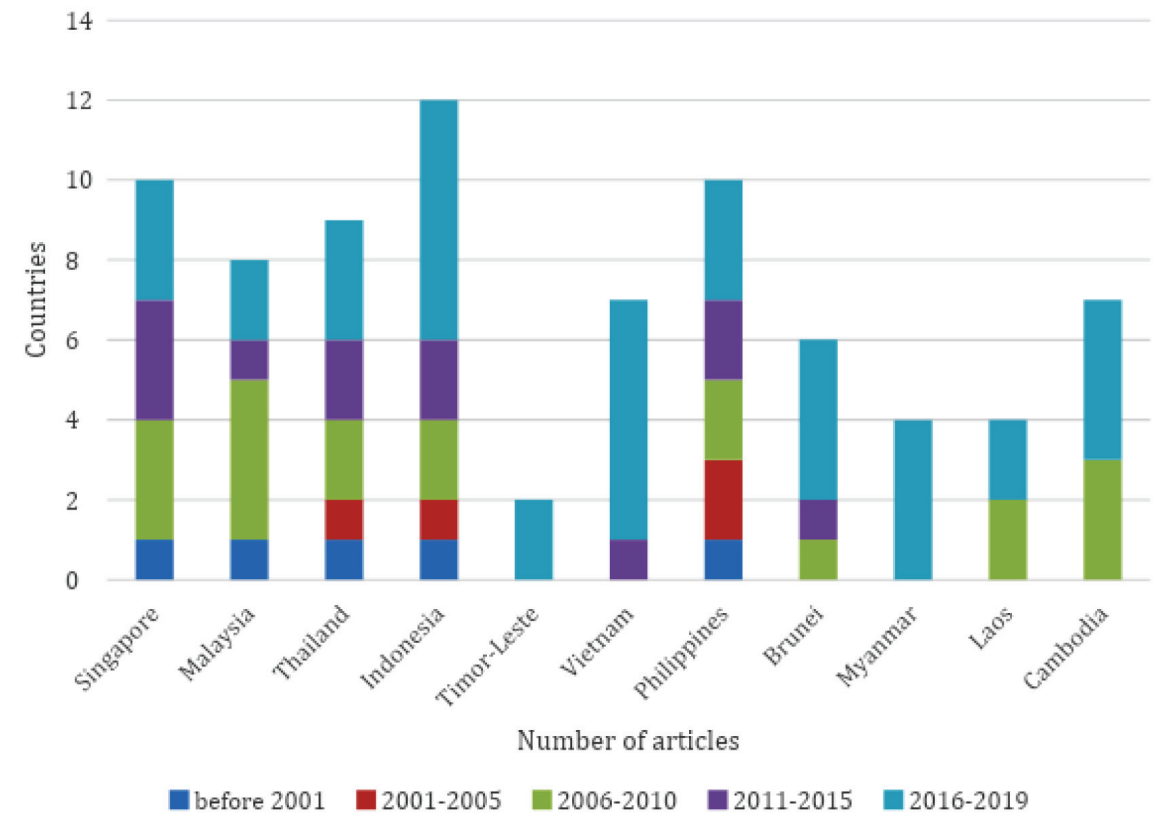

There are articles mentioning the importance of having independent and fully functioning ACAs. Quah (2014) argues that Singapore has been successful in combating police corruption, not only due to the strong commitment of the government but also their measures in establishing the independent ACAs. Police corruption was rampant in this country before the time of the colonial period. In 1937, the Singapore Anti-Corruption Branch (ACB) was established; however, it was ineffective because it was under the control of the Criminal Investigation Department (CID) of the Singapore Police Force (SPF). Ironically, this meant those police officers were responsible for combating police corruption. Additionally, it had limited power and resources to combat corruption since there were other priorities, such as dealing with felony and misdemeanour crimes. It was challenging to have a small number of police officers to combat corruption within their department and solve the many corruption cases (Quah, 2014; 2013). However, the story changed when the Corrupt Practices Investigation Bureau (CPIB) 
was created in 1952. CPIB, a single and independent ACA, had sufficient funds, personnel, and power in operating and functioning.

Furthermore, Thalib, Ramadhan, and Djanggih (2017) found some internal issues in investigating corruption practice in the Regional Police of Riau Islands in Indonesia. First, there was the limited capacity and capability of human resources. They did not have enough expertise in investigating corruption cases. Second, the facilities were of low quality and insufficient. This made it difficult to support the process of investigating corruption cases. Third, there was a limited budget for investigating corruption cases.

Likewise, Abdullah (2008) found that the Malaysian ACA has faced many challenges since its establishment in 1967. First, the ACA police personnel were incapable of investigating corruption. Additionally, police officers were unwilling to be involved in investigations in police related departments due to their concerns for their future. Although the ACA was reorganized, other issues such as incapability and lack of power to investigate and prosecute high-ranking officers existed. For example, the ACA only investigated around 3,700 corruption cases among 38,000 cases filed with this institution between 2001 and 2004. Fundamentally, the ACA only resolved small and medium-sized cases rather than the larger cases that involved high-ranking officers and elite groups (Abdullah, 2008). Similarly, Beh (2011) described the ACA in Malaysia as a powerless institution when it came to prosecuting corrupt police officers. Although the ACA has different divisions and comprehensive functions related to prevention of and fighting against corruption, it has limited power in investigating and recommending prosecutions. This is because the attorney general is the one who has the authority to make final decisions regarding corruption cases. Therefore, ACAs are expected to be independent and fully functioning with separate staff from police departments and resources. Without powerful and independent ACAs, police corruption could be very difficult to address.

\section{Political will}

Figure 10 demonstrates the number of articles about police corruption in Southeast Asia which mention the concept of political will in different time periods. It is worthwhile to note that in Figure 14 political will appears to be popularly mentioned in police corruption-related articles throughout the entire time period. Figure 15 shows that political will has been suggested the most in articles on the Philippines with 16 followed by Singapore and Indonesia with 13 articles equally. However, there were only 6 articles about police corruption in both Myanmar and Timor-Leste. Political will appears in three articles discussing police corruption in the Philippines. Before 2000 and from 2001 to 2005, it appeared in one article in each of Singapore, Malaysia, Thailand, and Indonesia. Conversely, there is no article about political will for the remaining countries. From 2006 to 2010, political will was mentioned most frequently in the context of police corruption in Cambodia. From 2011 to 2015, it was most frequently mentioned in Singapore. From 2016 to 2019, Vietnam is shown as the country where the concept was most mentioned. However, political will appears least in Timor-Leste and Laos in most of the periods. 


\section{Figure 10: Number of articles raising political will at different time periods in Southeast Asia}

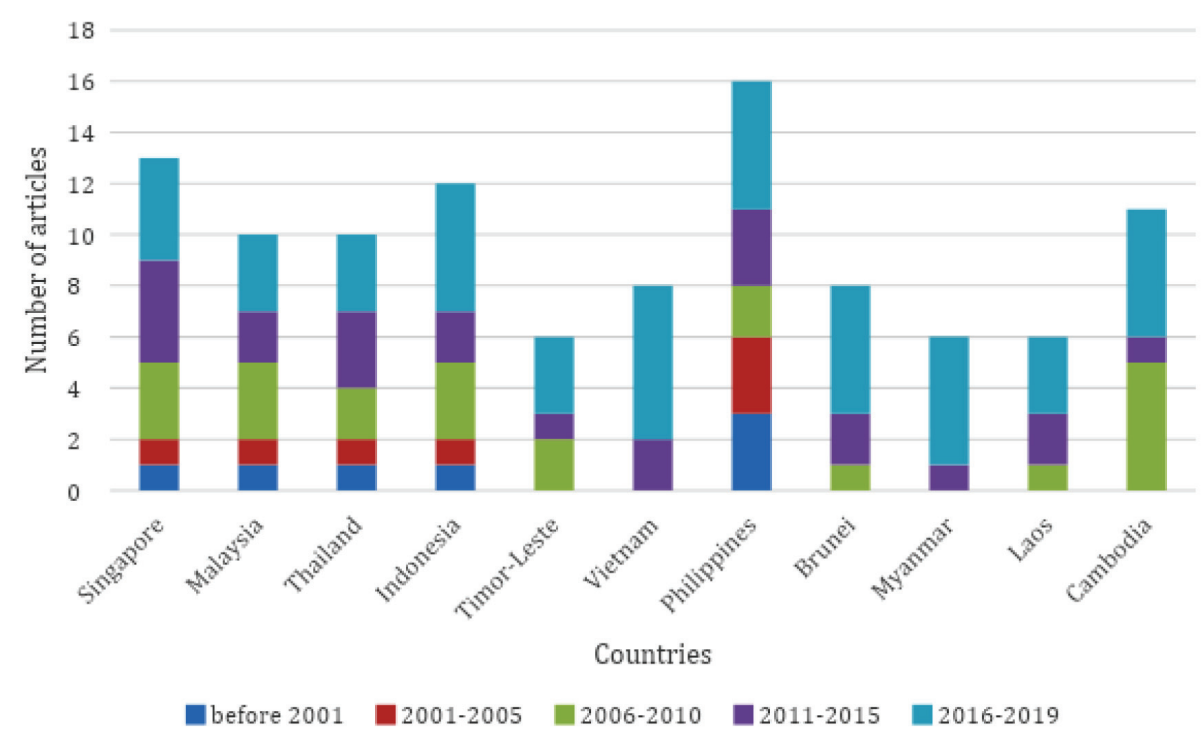

Political will, therefore, is the primary focus in combating police corruption. Political will is regarded as a significant tool in combating both corruption in general and police corruption. For instance, in many articles, Quah (2006; 2011; 2013; 2014) argues that corruption will continue to exist at all levels if the government of the country does not have the political will to combat corruption. This theme has been emphasized increasingly after 2005 in most countries. For instance, Ear and Leonard (2005), Vu (2017), and Gregory (2016) agree and add that without the wish to reduce police corruption, governments will neither take effective measures nor be held accountable in the fight against police corruption. That is, there will be ineffective law, and insufficient human, financial, and technical resources to curb police corruption. Ear (2016) argues that the pervasiveness of corruption, including police corruption and the limited anti-corruption measures in Cambodia, are because the government does not have a strong enough political will to curb this issue. $\mathrm{Vu}(2017)$ asserts that political will is of crucial importance in curbing corruption. Political will ensures ACAs are provided with sufficient resources and institutional arrangements, the willingness and support of politicians in the operation of institutions created, and reinforcement of the effectiveness of these institutions through wise political decisions. Political will is described as a supporting factor that can reduce police corruption, while lack of political will hinders the process of combating corruption. The extent of successfully combating police corruption depends on the degree of political will that a government has.

\section{Discussion and Conclusion}

Although police corruption in Southeast Asia is getting more attention from public management scholars, there are very few articles about the police. Furthermore, Selth (2012) recognizes that police corruption issues are often un- 
der-documented in academic literature on Southeast Asia. Few facts and data about police corruption and misconduct are revealed to the public. In the studies we analysed, police corruption issues are analysed as very general descriptions or only with anecdotal examples, rather than systematically examining the whole public management system in the police or focusing specifically on any significant corruption agenda. This might be due to limited data accessibility and availability, or the issue might not be a priority area of public management studies for scholars in the region, or local scholars might not be encouraged to do research on this topic since police corruption is such a sensitive issue to be freely studying and publishing. However, Singapore, Indonesia and the Philippines have been studied relatively more by scholars and compared to other countries in the region, and they seem to have more sufficient information and data to analyse and draw conclusions with.

Most of the articles are written by domestic scholars or international scholars located domestically in the country of interest in their studies. Domestic researchers could have more understanding of the local contexts of the country or countries. However, it does not necessarily mean international scholars don't have enough knowledge to study police corruption in Southeast Asia. Rather, international scholars, although located domestically, tend to offer fresh perspectives with some new insights about these corruption issues, and contribute to the body of knowledge in different ways.

The realities of police corruption in Southeast Asia are quite complicated and there is no simple solution to managing police corruption. A police workforce is exposed to various bundles of contexts and practices, which creates different pathways to approaching police corruption or misconduct. Previous research in Southeast Asia offers analysis on strategies to combat corruption or examine factors affecting the effectiveness of those strategies. Interestingly, while some researchers argue that the police should be empowered to handle corruption cases, others suggest that police officers should be under stricter control by independent entities. There are many articles suggesting police reforms to manage corruption but McCusker (2006) states that the effectiveness of anti-corruption measures needs persistent long-running efforts to change the culture.

This research aimed to collect and summarize articles about police corruption in Southeast Asia. Previous research that attempted in-depth analysis on the phenomenon are appreciated, but we call for more research efforts to collect data on what is happening in the region as to public safety, or apply rigorous methodology to gauge the understanding of the reality. Without appropriate understanding of the problem of interest, the suggestions for reforms or strategies may be misleading. Because of the nature of corrupt behaviour and police misconduct, office statistics or reported cases only offer an incomplete picture of what the realworld causes are. If quantitative data is limited, then researchers may approach the phenomenon differently using qualitative analysis with purposive sampling for accessing hard-to-reach groups of informants. In the research process, there may be implicit or explicit risks and barriers to access, privacy, and confidentiality when studying police corruption in Southeast Asia, but any research aimed at indepth understanding of the root cause of the problem is of great merit. 


\section{REFERENCES}

1. Abdullah, N.R.W. (2008). Eradicating Corruption: The Malaysian Experience. JOAAG, vol. 3, no 1 , pp. 1-12.

2. Ackerman, J. (2004). Co-governance for Accountability: Beyond "Exit" and "Voice". World Development, vol. 32, no 3, pp. 447-463.

3. Allen, B., Tamindael, L.E., Bickerton, S.H. \& Cho, W. (2020). Does Citizen Coproduction Lead to Better Urban Services in Smart Cities Projects? An Empirical Study on E-Participation in a Mobile Big Data Platform. Government Information Quarterly, vol. 37, no 1, pp. 101-412.

4. Andvig, J.C. \& Fjeldstad, O.H. (2008). Crime, Poverty and Police Corruption in Non-Rich Countries. Norsk Utenrikspolitisk Institutt, Norway.

5. Arrigo, B.A. \& Claussen, N. (2003). Police Corruption and Psychological Testing: A Strategy for Pre-Employment Screening. International Journal of Offender Therapy and Comparative Criminology, vol. 47, no 3, pp. 272-290.

6. Bayley, D.H. \& Perito, R. (2011). Police corruption: What Past Scandals Teach About Current Challenges? US Institute of Peace.

7. Beh, L. (2011). Public Ethics and Corruption in Malaysia. In: E. M. Berman (Ed.). Public Administration in Southeast Asia (171-192). London: CRC Press, the Taylor \& Francis Group.

8. Benington, J. (2007), Competing Paradigms for Public Leadership and Management. Coventry, Institute of Governance and Public Management.

9. Bhargava, V. (2015). Engaging Citizens and Civil Society to Promote Good Governance and Development Effectiveness. ADB. Available at: https://www.adb.org/sites/default/files/publication/172999/ governance-brief-23-engaging-citizens-and-civil-society.pdf (accessed: 17 June, 2020).

10. Botero, J., Ponce, A. \& Shleifer, A. (2012). Education and the Quality of Government (No. w18119). National Bureau of Economic Research.

11. Brinkerhoff, D.W. (2000). Assessing Political Will for Anti-Corruption Efforts: An Analytical Framework. Public Administration and Development, no 20, pp. 239-252.

12. Broadhurst, R. \& Bouhours, T. (2009). Policing in Cambodia: Legitimacy in the making? Policing and Society, vol. 19, no 2, pp. 174-190.

13. Bruce, D. (2008). Benign Neglect? The Politics and Practice of Controlling Police Corruption in South Africa. In: Crime, Poverty and Police Corruption Annual Bank Conference on Development Economics, pp. 1-21. Cape Town, South Africa: The Centre for the Study of Violence and Reconciliation.

14. Buttle, J.W., Davies, S.G. \& Meliala, A.E. (2016). A Cultural Constraints Theory of Police Corruption: Understanding the Persistence of Police Corruption in Contemporary Indonesia. Australian \& New Zealand Journal of Criminology, vol. 49, no 3, pp. 437-454. Available at: DOI: 10.1177/0004865815573875 (accessed: 17 June, 2020).

15. Carvajal, R. (1999). Large-Scale Corruption: Definition, Causes, and Cures. Systemic Practice and Action Research, vol. 12, no 4, pp. 335-353.

16. Case, W. (2008). Malaysia in 2007: High Corruption and Low Opposition. Asian Survey, vol. XLVIII, no 1, pp. 47-54. 
17. Cho, W. (2017). Change and Continuity in Police Organizations: Institution, Legitimacy, And Democratization. The Experience of Democracy and Bureaucracy in South Korea. Emerald Publishing Limited, no 2, pp. 113-139.

18. Cho, W. \& Ho, A.T. (2018). Does Neighborhood Crime Matter? A Multi-Year Survey Study on Perceptions of Race, Victimization, and Public Safety. International Journal of Law, Crime and Justice, no 55, pp. 13-26.

19. Curtain, R. (2006). Crisis in Timor Leste: Looking Beyond the Surface Reality for Causes and Solutions Series. State Society and Society in Melanesia Project. Working Paper The Australian National University: Canberra.

20. Dantzker, M.L. (2011). Psychological Pre-Employment Screening for Police Candidates: Seeking Consistency if Not Standardization. Professional Psychology: Research and Practice, vol. 42, no 3, pp. 276-283.

21. Davies, S., Stone, L. \& Buttle, J. (2016). Covering Cops: Critical Reporting of Indonesian Police Corruption. Pacific Journalism Review, vol. 22, no 2, pp. 185-201. Available at: https:// doi.org/10.24135/pjr.v22i2.61 (accessed: 17 June, 2020).

22. De Graaf, G. (2007). Causes of Corruption: Towards a Contextual Theory of Corruption. Public Administration Quarterly, vol. 31, no 1, pp. 39-86.

23. De Montfort University. (1989). How to Undertake the Literature Search and Review for Dissertations and Final Year Projects. Available at: http://www.library.dmu.ac.uk/Images/Howto/ LiteratureSearch.pdf (accessed: 17 June, 2020).

24. Di Puppo, L. (2010). Police Reform in Georgia: Cracks in an Anti-Corruption Success Story. U4 Practice Insight, no 2, pp. 1-5.

25. Dimant, E. (2013). The Nature of Corruption: An Interdisciplinary Perspective. Economics discussion papers, no 59, pp. 1-57.

26. Dutta, N., Kar, S., \& Roy, S. (2011). Informal Sector and Corruption: An Empirical Investigation for India. IZA Discussion Paper, no 5579, pp. 1-35.

27. Ear, S. \& Leonard, D.K. (2005). The Political Economy of Aid, Governance, and Policymaking: Cambodia in Global, National, and Sectoral Perspectives. ProQuest Dissertations and Theses.

28. Endres, K.W. (2014). Making Law: Small-Scale Trade and Corrupt Exceptions at the Vietnam-China Border. American Anthropologist, vol. 116, no 3, 611-625.

29. Feinberg, G. (2009). Crime Prevention and Community Safety. Palgrave Macmillan, vol. 11, no 4, pp. 277-296.

30. Gillespie, J. (2001). Self-Interest and Ideology: Bureaucratic Corruption in Vietnam. Australian Journal of Asian Law, vol. 3, no 1, pp. 1-36.

31. Girodo, M. (1998). Undercover Probes of Police Corruption: Risk Factors in Proactive Internal Affairs Investigations. Behavioral Sciences \& the Law, vol. 16, no 4, pp. 479-496.

32. Gogtay, N.J. \& Thatte, U.M. (2017). Statistics for Researchers. Journal of the Association of Physicians of India, no 65, pp. 78-85.

33. Goldsmith, A. \& Dinnen, S. (2007). Transnational Police Building: Critical Lessons from Timor-Leste and Solomon Islands. Third World Quarterly, vol. 28, no 6, pp. 1091-1109.

34. Gonzalez, E.T. (2011). Public Ethics and Corruption in the Philippines. In: E.M. Berman (Ed.). Public Administration in Southeast Asia, pp. 386-396. London: CRC Press, the Taylor \& Francis Group. 
35. Graycar, A. \& Sidebottom, A. (2012). Corruption and Control: A Corruption Reduction Approach. Journal of Financial Crime, vol. 19, no 4, pp. 384-399.

36. Gregory, R. (2016). Combating Corruption in Vietnam: A Commentary. Asian Education and Development Studies, 5(2), 227-243. https://doi.org/10.1108/AEDS-01-2016-0010

37. Gutierrez-Garcia, J.O. \& Rodríguez, L.-F. (2016). Social Determinants of Police Corruption: Toward Public Policies for the Prevention of Police Corruption. Policy Studies, vol. 37, no 3, pp. 1-20. Available at: DOI: 10.1080/01442872.2016.1144735 (accessed: 17 June, 2020).

38. Hardoon, D. \& Heinrich, F. (2013). Global Corruption Barometer. Berlin, Germany: Transparency International. The Global Coalition against Corruption.

39. Hayashi, K., Small, W., Csete, J., Hattirat, S., Kerr, T. \& Koester, S. (2013). Experiences with Policing among People Who Inject Drugs in Bangkok, Thailand: A Qualitative Study (Experiences with Policing among Thai PWID). Plos Medicine, December, 12, e1001570. Available at: https://doi.org/10.1371/journal.pmed.1001570 (accessed: 17 June, 2020).

40. Hul, R. (2015). Low-Ranking Police, Soldiers to See Salary Increases. The Cambodia Daily. Available at: https://www.cambodiadaily.com/news/low-ranking-police-soldiers-to-see-salaryincreases-76041/ (accessed: 17 June, 2020).

41. Huberts, L.W. \& Six, F.E. (2012). Local Integrity Systems: Toward a Framework for Comparative Analysis and Assessment. Public Integrity, vol. 14, no 2, pp. 151-172.

42. Ivković, S.K. (2003). To Serve and Collect: Measuring Police Corruption. Journal of Criminal Law and Criminology, vol. 93, no 2, pp. 593-650.

43. Jain, A.K. (2001). Corruption: A Review. Journal of Economic Surveys, vol. 15, no 1, pp. 71-121.

44. Jensen, S. \& Hapal, K. (2018). Police Violence and Corruption in the Philippines: Violent Exchange and the War on Drugs. (Report). Journal of Current Southeast Asian Affairs, vol. 37, no 2, pp. 39-62. Available at: https://doi.org/10.1177/186810341803700202 (accessed: 17 June, 2020).

45. Johnston, M. (2005). Syndromes of Corruption: Wealth, Power and Democracy. Cambridge University Press.

46. Johnston, M. (2013). Corruption, Contention, and Reform: The Power of Deep Democratization. Cambridge University Press.

47. Jones, D. (2016). Combatting Corruption in Brunei Darussalam. Asian Education and Development Studies, vol. 5, no 2, pp. 141-158. Available at: https://doi.org/10.1108/AEDS-012016-0007 (accessed: 17 June, 2020).

48. Kaushik, M. \& Mathur B. (2014). Data Analysis of Students Marks with Descriptive Statistics. International Journal on Recent and Innovation Trends in Computing and Communication, vol. 2, no 5, pp. 1188-1190. ISSN: 2321-8169

49. Keo, C., Broadhurst, R. \& Bouhours, T. (2010). Inside the Cambodian Correctional System. British Journal of Community Justice, vol. 8, no 3, pp. 7-22.

50. Kies, M.F. (2011). Policing the Police: Freedom of the Press, the Right to Privacy, and Civilian Recordings of Police Activity. The George Washington Law Review, vol. 80, no 1, pp. 274-310.

51. Kis-Katos, K., \& Schulze, G. (2013). Corruption in Southeast Asia: A Survey of Recent Research. Asian-Pacific Economic Literature, vol. 27, no 1, pp. 79-109.

52. Klaver, J.J. (2013). Law Enforcement Ethics and Misconduct. In: Law Enforcement Ethics: Classic and Contemporary Issues. 1st ed. B.D. Fitch (Ed.), pp. 3-28. Thousand Oaks, CA: Sage. 
53. Lam, N.M.K. (2000). Government Intervention in the Economy: A Comparative Analysis of Singapore and Hong Kong. Public Administration and Development, vol. 20, no 5, pp. 397-421.

54. Lamboo, T., Lasthuizen, K. \& Huberts, L.W. (2008). How to Encourage Ethical Behavior: The Impact of Police Leadership on Police Officers Taking Gratuities. In: Ethics and Integrity of Governance: Perspectives Across Frontiers. 1st ed. W.J.C. Leo, J. Maesschalck, and L.C. Jurkiewicz (Eds), pp. 159-180. Cheltenham: Edward Elgar Publishing.

55. Lasthuizen, K., Huberts, L. \& Heres, L. (2011). How to Measure Integrity Violations: Towards a Validated Typology of Unethical Behavior. Public Management Review, vol. 13, no 3, pp. 383-408.

56. Linton, S. (2001). Cambodia, East Timor and Sierra Leone: Experiments in International Justice. Criminal Law Forum, vol. 12, no 2, pp. 185-246.

57. Macintyre, S., Prenzler, T. \& Chapman, J. (2008). Early Intervention to Reduce Complaints: An Australian Victoria Police Initiative. International Journal of Police Science and Management, vol. 10, no 2, pp. 238-250.

58. Matthews, N. (2012). Water Grabbing in the Mekong Basin - An Analysis of the Winners and Losers of Thailand's Hydropower Development in Lao PDR. Water Alternatives, vol. 5, no 2, pp. 392-411.

59. McCusker, R. (2006). Review of Anti-Corruption Strategies. Technical and background paper, no 23, Australian Institute of Criminology, Canberra, Australia.

60. Mendelson, S.E. (2015). Why Governments Target Civil Society and What Can Be Done in Response. Center for Strategic \& International Studies: Washington, DC.

61. Mullen, B. (1989). Advanced BASIC Meta-Analysis. Hillsdale, NJ: Lawrence Erlbaum Associates.

62. Nalla, M. \& Mamayek, C. (2013). Democratic Policing, Police Accountability and Citizen Oversight in Asia: An Exploratory Study. Police Practice and Research, vol. 14, no 2, pp. 117-129.

63. Newburn, T. (1999). Understanding and Preventing Police Corruption: Lessons from the Literature. London: Policing and Reducing Crime Unit Research, Development and Statistics Directorate.

64. Newham, G. (2000). Towards Understanding and Combating Police Corruption. Crime and Conflict, no 19, pp. 21-25.

65. Nye, J. S. (1967). Corruption and Economic Development: A Cost-Benefit Analysis. American Political Science Review, vol. 61, no 2, pp. 417-427.

66. OECD. (2013). Specialised Anti-Corruption Institutions: OECD Publishing.

67. Parlina, I. \& Sundaryani, F.S. (2015). Jokowi Raises Police and Soldiers' Salaries. The Jakarta Post. Available at: https://www.thejakartapost.com/news/2015/06/13/jokowi-raises-policeand-soldiers-salaries.html (accessed: 17 June, 2020).

68. Persson, A., Rothstein, B. \& Teorell, J. (2013). Why Anticorruption Reforms Fail-Systemic Corruption as a Collective Action Problem. Governance: An International Journal of Policy, Administration, and Institutions, vol. 26, no 3, pp. 449-471.

69. Plimmer, G., Cho, W. \& Franken, E. (2019). Competing Demands and Variable Managers. Public Sector, vol. 42, no 3, p. 3.

70. Polinsky, A.M. \& Shavell, S. (2001). Corruption and Optimal Law Enforcement. Journal of Public Economics, vol. 81, no 1, pp. 1-24. 
71. Prateeppornnarong, D. \& Young, R. (2019). A Critique of the Internal Complaints System Of The Thai Police. Policing and Society, vol. 29, no 1, pp. 18-35.

72. Prenzler, T. (2009). Police Corruption: Preventing Misconduct and Maintaining Integrity. Boca Raton, FL: CRC Press.

73. Prenzler, T. \& Ronken, C. (2001). Police Integrity Testing in Australia. Criminology and Criminal Justice, vol. 1, no 3, pp. 319-342.

74. Prenzler, T. \& Ronken, C. (2003). A Survey of Innovations in the Development and Maintenance of Ethical Standards by Australian Police Departments. Police Practice and Research, vol. 4, no 2, pp. 149-161.

75. Punch, M. (1994). Rotten Barrels: Systemic Origins of Corruption. In: Strategieen Voor Corruptie-Beheersing bij de Politie. 1st ed. Edited by E.W. Kolthoff, pp. 19-44. Gouda Quint: Arnhem.

76. Punch, M. (2000). Police Corruption and Its Prevention. European Journal on Criminal Policy and Research, vol. 8, no 3, pp. 301-324.

77. Quah, J.S.T. (2006). Preventing Police Corruption in Singapore: The Role of Recruitment, Training and Socialisation. Asia Pacific Journal of Public Administration, vol. 28, no 1, pp. 59-75. Available at: DOI: 10.1080/23276665.2006.10779315 (accessed: 17 June, 2020).

78. Quah, J.S.T. (2011). Curbing Corruption in Asian Countries: An Impossible Dream? Vol. 20. Emerald Group Publishing.

79. Quah, J.S.T. (2013). Different Paths to Curbing Corruption: Lessons from Denmark, Finland, Hong Kong, New Zealand and Singapore. Edited by Jon S.T. Quah, Anti-Corruption Consultant, Singapore (1st.). United Kingdom: Emerald.

80. Quah, J. S.T. (2014). Policing in Asia - Reforms and Challenges- Curbing Police Corruption in Singapore: Lessons for Other Asian Countries. Asian Education and Development Studies, vol. 3, no 3, pp. 186-222.

81. Rand, J. \& Tarp, F. (2012). Firm-Level Corruption in Vietnam. Economic Development and Cultural Change, vol. 60, no 3, pp. 571-595.

82. Rugege, S. (2006). Judicial Independence in Rwanda. Global Business and Development Law Journal, no 19, pp. 411-425.

83. Sagarik, D., Chansukree, P., Cho, W. \& Berman, E. (2018). E-Government 4.0 in Thailand: The Role of Central Agencies. Information Polity, vol. 23, no 3, pp. 343-353.

84. Selth, A. (2012). Myanmar's Police Forces: Coercion, Continuity and Change. Contemporary Southeast Asia, vol. 34, no 1, pp. 53-79.

85. Senior, I. (2006). Corruption - the World's Big C: Cases, Causes, Consequences, Cures. London: Institute of Economic Affairs.

86. Setiyono, B. \& Mcleod, R. (2010). Civil Society Organisations' Contribution to the Anti-Corruption Movement in Indonesia. Bulletin of Indonesian Economic Studies, vol. 46, no 3, pp. 347-370.

87. Sherman, L.W. (1978a). Controlling Police Corruption: The Effects of Reform Policies - Summary Report. National Institute of Law Enforcement and Criminal Justice, Law Enforcement Assistance Administration, US Department of Justice.

88. Sherman, L.W. (1978b). Scandal and Reform: Controlling Police Corruption. Berkeley: University of California Press. 
89. Small, M. W., \& Dickie, L. (2003). Conjoining Ethical Theory and Practice: An Australian Study of Business, Accounting, and Police Service Organizations. Teaching Business Ethics, vol. 7, no 4, pp. 379-393.

90. Stuart-Fox, M. (2008). The Persistence of Political Culture in Laos and Cambodia. Südostasien Aktuell, no 3, pp. 33-57.

91. Thalib, H., Ramadhan, A. \& Djanggih, H. (2017). The Corruption Investigation in the Regional Police of Riau Islands, Indonesia. Rechtsidee, vol. 4, no 1, pp. 71-86.

92. The International Association of Chiefs of Police (2014). Model Policy on Standards of Conduct. Available at: http://www.theiacp.org/Model-Policy-on-Standards-of-Conduct (accessed: 17 June, 2020).

93. The World Bank (1997). Helping Countries Combat Corruption: The Role of the World Bank. Washington, DC: World Bank Group.

94. The World Bank (2000). Anticorruption in Transition - A Contribution to the Policy Debate. Available at: http://siteresources.worldbank.org/INTWBIGOVANTCOR/Resources/ contribution.pdf (accessed: 17 June, 2020).

95. The World Bank (2006). Public Participation Best Practice Principles. International Association for Impact Assessment. Available at: http://siteresources.worldbank.org/INTRANETEN VIRONMENT/1705772-1177181681657/21309010/IAIAPrinciples_PublicParticipation.pdf (accessed: 17 June, 2020).

96. The World Bank (2018). Worldwide Governance Indicators. Available at: http://info. worldbank.org/governance/wgi/\#home (accessed: 06 March, 2019).

97. Thompson, G., Staddon, A. \& Stapenhurst, R. (2018). Motivation of Legislators and Political Will. Public Integrity, pp. 1-20. Available at: https://doi.org/10.1080/10999922.2018.1511669 (accessed: 17 June, 2020).

98. Transparency International (2017). People and Corruption: Citizens'Voices from Around the World-Global Corruption Barometer. Available at: https://www.transparency.org/whatwedo/ publication/people_and_corruption_citizens_voices_from_around_the_world (accessed: 02 September, 2019).

99. Transparency International (2011). 2010/11g Global Corruption Barometer. Available at: https://www.transparency.org/gcb201011/in_detail (accessed: 26 March, 2019).

100. Transparency International (2012). Arresting Corruption in the police. The Global Experience of Police Corruption Reform Efforts. UK.

101. Transparency International. (2014). Global Corruption Barometer 2013. Available at: http:// www.transparency.org/gcb2013/in_detail (accessed: 17 June, 2020).

102. Transparency International (2015a). How do you Define Corruption? Available at: http:// www.transparency.org/what-is-corruption/?gclid=CjwKEAjw7uKwBRDUlJvRo- (accessed: 17 June, 2020).

103. Transparency International (2015b). Anti-Corruption Glossary. Available at: https://www. transparency.org/glossary/term/political_will (accessed: 17 June, 2020).

104. Transparency International (2018a). Best Practices in addressing police-related corruption. U4 Anti-Corruption, CMI.

105. Transparency International (2018b). Global Corruption Barometer 2015/16/17. Available at: https://www.transparency.org/research/gcb/gcb_2015_16/0 (accessed: 02 April, 2019). 
106. Transparency International (2019). Global Corruption Barometer: citizens' voices from around the world. Available at: https://www.transparency.org/news/feature/global_corruption_ barometer_citizens_voices_from_around_the_world (available at: 16 March, 2019).

107. U4 Anti-Corruption Resource Centre (2010). UNCAC in a Nutshell. Available at: http://www. cmi.no/publications/file/3769-uncac-in-a-nutshell.pdf (accessed: 17 June, 2020).

108. UNDP (1994). Program Support Document. UNDP Public Administration Reform Program. VIE/92/002.

109. UNDP (2011). Capacity Assessment of Anti-Corruption Agencies.

110. Verdenicci, S. \& Hough, D. (2015). People Power and Anti-Corruption: Demystifying Citizen-Centred Approaches. Crime, Law and Social Change, vol. 64, no 1, pp. 23-35.

111. Vichit-Vadakan, J. (2011). Public Ethics and Corruption in Thailand. In: E.M. Berman (Ed.). Public Administration in Southeast Asia, pp. 79-94. London: CRC Press, the Taylor \& Francis Group.

112. Vu, A.D. (2017). Tiền là Tiên là Phật: Investigating the Persistence of Corruption in Vietnam. In: Edited by M. Macaulay \& B. Ryan. Victoria University of Wellington.

113. Williams, D. \& Dupuy, K. (2018). Will REDD Safeguards Mitigate Corruption? Qualitative Evidence from Southeast Asia. The Journal of Development Studies, vol. 55, no 10, pp. 1-16.

114. Williams, H. (2002). Core Factors of Police Corruption Across the World. Forum on Crime and Society, vol. 2, no 1, pp. 85-99.

115. Wirtz, J. \& Chung, C.M.Y. (2001). Marketing in Singapore: Macro Trends and Their Implications for Marketing Management for 2002 and the Years Beyond. Research Paper Series no 2001-033, National University of Singapore.

116. Zhang, Y. \& Lavena, C. (2015). Government Anti-Corruption Strategies: A Cross-Cultural Perspective: CRC Press.

\section{ACRONYMS}

ACA/ACAs: Anti-Corruption Agency/ Anti-Corruption Agencies

CID: Criminal Investigation Department

CSOs: Civil Society Organizations

OECD: Organization for Economic Co-operation and Development

SPF: Singapore Police Force

TI: Transparency International

UNDP: United Nations Development Program

CPIB: Corrupt Practices Investigation Bureau 